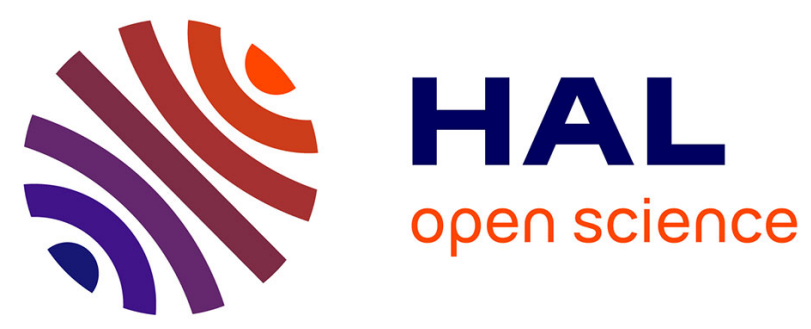

\title{
4-Benzoyl-3,4-dihydro-2 $\mathrm{H}$ \\ -1,4-benzoxazine-2-carbonitrile: refinement using a multipolar atom model
}

Krzysztof Ejsmont, Jean-Pierre Joly, Emmanuel Wenger, Benoît Guillot, Christian Jelsch

\section{To cite this version:}

Krzysztof Ejsmont, Jean-Pierre Joly, Emmanuel Wenger, Benoît Guillot, Christian Jelsch. 4-Benzoyl3,4-dihydro-2 H -1,4-benzoxazine-2-carbonitrile: refinement using a multipolar atom model. Acta Crystallographica Section C: Crystal Structure Communications [1968-2013], 2009, 65 (7), pp.o342 o344. 10.1107/S0108270109019544 . hal-01713019

\section{HAL Id: hal-01713019 \\ https://hal.science/hal-01713019}

Submitted on 20 Feb 2018

HAL is a multi-disciplinary open access archive for the deposit and dissemination of scientific research documents, whether they are published or not. The documents may come from teaching and research institutions in France or abroad, or from public or private research centers.
L'archive ouverte pluridisciplinaire HAL, est destinée au dépôt et à la diffusion de documents scientifiques de niveau recherche, publiés ou non, émanant des établissements d'enseignement et de recherche français ou étrangers, des laboratoires publics ou privés. 


\section{Communications}

ISSN 0108-2701

Editor: Anthony Linden

\section{4-Benzoyl-3,4-dihydro-2 $\mathrm{H}$-1,4-benzoxazine-2-carbonitrile: refinement using a multipolar atom model}

\section{Krzysztof Ejsmont, Jean-Pierre Joly, Emmanuel Wenger, Benoit Guillot and Christian Jelsch}

Acta Cryst. (2009). C65, o342-0344

Copyright (C) International Union of Crystallography

Author(s) of this paper may load this reprint on their own web site or institutional repository provided that this cover page is retained. Republication of this article or its storage in electronic databases other than as specified above is not permitted without prior permission in writing from the IUCr.

For further information see http://journals.iucr.org/services/authorrights.html

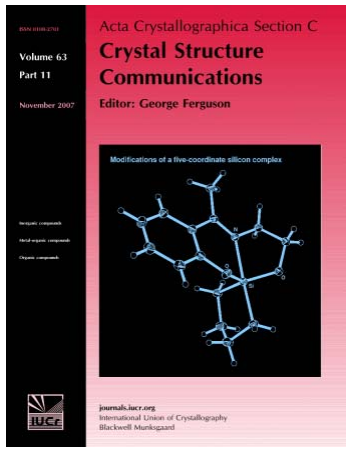

Acta Crystallographica Section C: Crystal Structure Communications specializes in the rapid dissemination of high-quality studies of crystal and molecular structures of interest in fields such as chemistry, biochemistry, mineralogy, pharmacology, physics and materials science. The numerical and text descriptions of each structure are submitted to the journal electronically as a Crystallographic Information File (CIF) and are checked and typeset automatically prior to peer review. The journal is well known for its high standards of structural reliability and presentation. Section $C$ publishes approximately 1000 structures per year; readers have access to an archive that includes high-quality structural data for over 10000 compounds.

Crystallography Journals Online is available from journals.iucr.org 
Acta Crystallographica Section C

Crystal Structure

Communications

ISSN 0108-2701

\section{4-Benzoyl-3,4-dihydro-2 $\mathrm{H}$-1,4-benz- oxazine-2-carbonitrile: refinement using a multipolar atom model}

\author{
Krzysztof Ejsmont, ${ }^{a}$ Jean-Pierre Joly, ${ }^{b}$ Emmanuel Wenger, ${ }^{\mathrm{c}}$ \\ Benoit Guillot ${ }^{\mathrm{C}}$ and Christian Jelsch ${ }^{\mathrm{C} *}$
}

${ }^{\text {a } F a c u l t y ~ o f ~ C h e m i s t r y, ~ U n i v e r s i t y ~ o f ~ O p o l e, ~ O l e s k a ~ 48, ~ 45-052 ~ O p o l e, ~ P o l a n d, ~}$

bUMR 7565 (SRSMC), Structure et Réactivité des Systèmes Moléculaires Complexes,

Nancy Université, Faculté des Sciences et Techniques, BP 70239, 54506

Vandoeuvre-lès-Nancy Cedex, France, and ${ }^{\mathrm{c}} \mathrm{CNRS}$ UMR $7036\left(\mathrm{CRM}^{2}\right)$, Laboratoire

de Cristallographie, Résonance Magnétique et Modélisations, Faculté des Sciences et

Techniques-UHP, BP 70239, 54506 Vandoeuvre-lès-Nancy Cedex, France

Correspondence e-mail: christian.jelsch@crm2.uhp-nancy.fr

Received 27 March 2009

Accepted 22 May 2009

Online 13 June 2009

The structural model for the title compound, $\mathrm{C}_{16} \mathrm{H}_{12} \mathrm{~N}_{2} \mathrm{O}_{2}$, was refined using a multipolar atom model transferred from an experimental electron-density database. The refinement showed some improvements of crystallographic statistical indices when compared with a conventional spherical neutralatom refinement. The title compound adopts a half-chair conformation. The amide $\mathrm{N}$ atom lies almost in the plane defined by the three neighbouring $\mathrm{C}$ atoms. In the crystal structure, molecules are linked by weak intermolecular $\mathrm{C}-\mathrm{H} \cdots \mathrm{O}$ and $\mathrm{C}-\mathrm{H} \cdots \pi$ hydrogen bonds.

\section{Comment}

1,4-Benzoxazines and their derivatives have attracted much attention over the past few decades (Bartsch \& Schwarz, 1982). Amongst these systems, cyano-substituted oxazines have been extensively studied (Bartsch \& Schwarz, 1983) and cycloaddition reactions with the cyano group reviewed (Myers \& Sircar, 1970). More recently, [3+2] cycloadditions of donoracceptor cyclopropanes and nitriles have found interesting applications in the field of glycal chemistry (Yu \& Pagenkopf, 2003). Recently, as part of a more complex 3,4-dihydropyrrole sugar-fused synthesis, we isolated the title $N$-acylated oxine, (II), from known racemic oxine (I) (Bartsch \& Schwarz, 1983).

The molecular structure of (II) exists in a half-chair conformation, as depicted with the atomic numbering scheme in Fig. 1. Amide atom N2 is almost exactly in the plane defined by the three neighbouring $\mathrm{C}$ atoms (C7, C14 and C15), with all four atoms within $0.05 \AA$ of the plane. The sum of the valence angles around the $\mathrm{N}$ atom of 359.7 (2) ${ }^{\circ}$ demonstrates clear $s p^{2}$ hybridization $\left(328^{\circ}\right.$ for $s p^{3}$ and $360^{\circ}$ for $\left.s p^{2}\right)$. The other geometric parameters of (II) (Table 1) are normal and compare well with those found in other crystal structures
(Bartsch \& Schwarz, 1983; Black et al., 1987; Garbauskas et al., 1985; Heine et al., 1988; Feng et al., 2007). Compound (II) also exhibits a slight shortening of the amide $\mathrm{N}-\mathrm{C}(=\mathrm{O})$ bond [1.369 (2) $\AA$ ] , indicative of partial double-bond character; this is typical behaviour for amides.<smiles>N#CC1CNc2ccccc2O1</smiles>

(I)

(1)

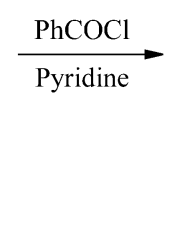

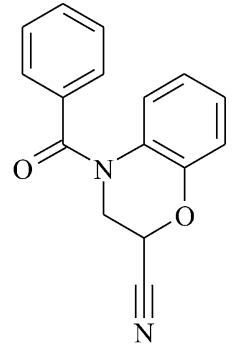

(II)
The crystal structure of (II) is presented in Fig. 2. Molecules of (II) are linked into a three-dimensional framework by three weak $\mathrm{C}-\mathrm{H} \cdots \mathrm{O}$ and a $\mathrm{C}-\mathrm{H} \cdots \pi$ hydrogen bond (Table 2 ).

Initially, in the independent atom model (IAM) refinement, a conventional spherical neutral atom model was applied. Scale factors, atomic positions and displacement parameters for all atoms were refined using the MOPRO program (Guillot et al., 2001; Jelsch et al., 2005) until convergence. In the experimental library multipolar atom model (ELMAM) refinement, the same parameters were varied but a multipolar charged atom model was applied. The electron-density parameters were transferred from the ELMAM library (PichonPesme et al., 2004; Zarychta et al., 2007) and subsequently kept fixed. Riding constraints on $\mathrm{H}$-atom isotropic displacement parameters were applied similarly in both refinements, which were carried out with the same diffraction data and using all reflections. The $\mathrm{H}-X$ distances were constrained to standard values in neutron diffraction studies (Allen, 1986) in the IAM and ELMAM refinements. The ELMAM refinement shows a slight improvement in statistical indexes when compared with the IAM refinement. The $I>2 \sigma(I)$ crystallographic factors are reduced from 7.32 to $6.09 \%$ for $R(F)$ and from 2.22 to $2.19 \%$ for $w R(F)$. The minimum and maximum peaks in the residual

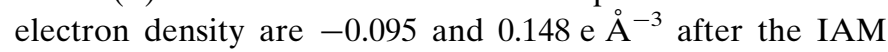

Figure 1

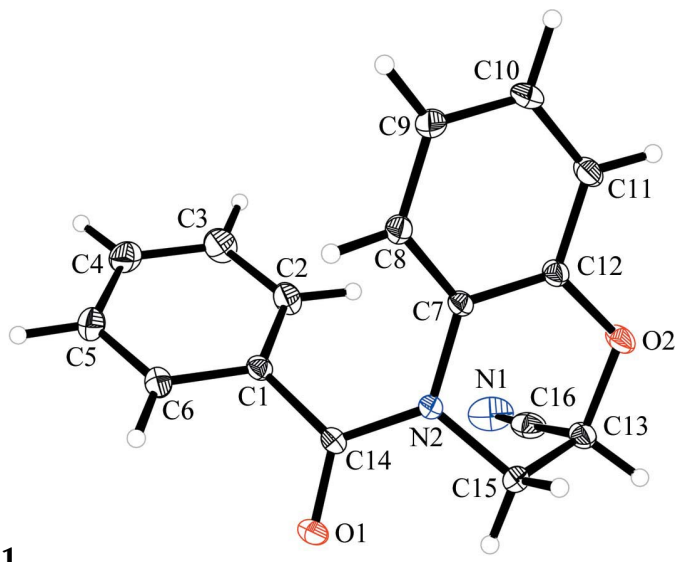

The molecular structure of (II), showing the atom-labelling scheme. Displacement ellipsoids are drawn at the $50 \%$ probability level and $\mathrm{H}$ atoms are shown as small spheres of arbitrary radii. 


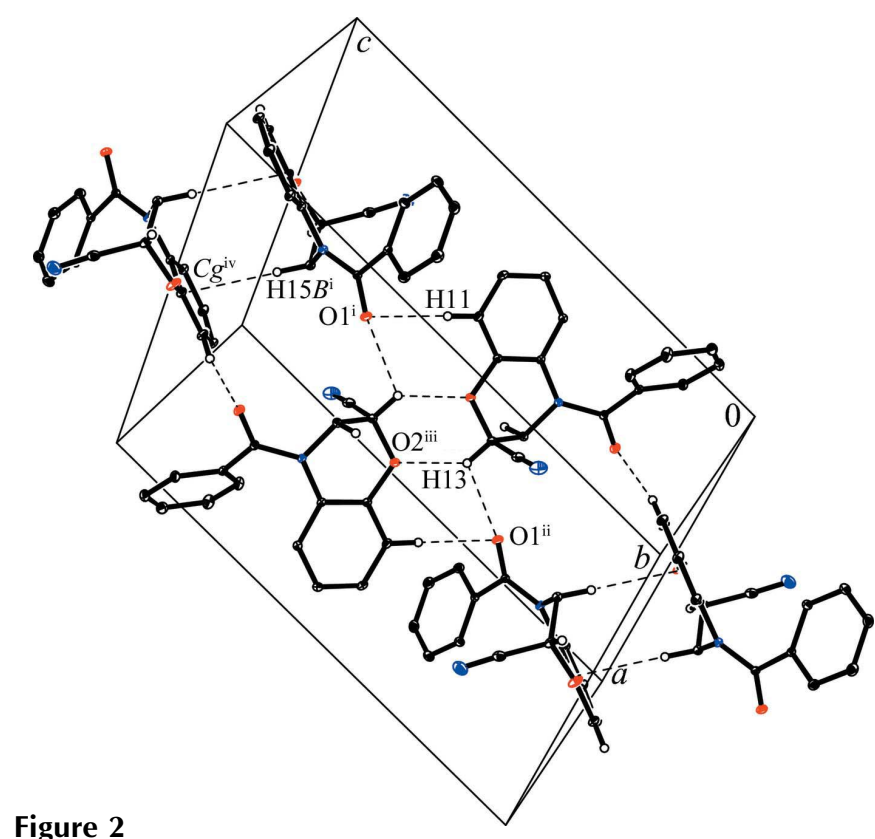

A packing diagram for (II). Dashed lines indicate hydrogen bonds. $\mathrm{Cg}$ is the centroid of the C7-C12 ring. [Symmetry codes: (i) $x,-y+\frac{1}{2}, z+\frac{1}{2}$; (ii) $-x+1, y+\frac{1}{2},-z+\frac{1}{2}$; (iii) $-x+1,-y+1,-z+1$; (iv) $-x+1,-y,-z+1$.]

refinement, and -0.103 and $0.139 \mathrm{e} \AA^{-3}$ after the ELMAM refinement. The improvement is not significant and indicates that the random noise in the residual Fourier map is here larger than the effect of not modelling the bonding electron density.

The largest effect of the multipole transfer on the crystallographic structure is observed for the atomic thermal motion (Jelsch et al., 1998). The average value of $U_{\text {eq }}$ (geometric mean of eigenvalues $U_{i}$ ) derived from the IAM refinement is $0.0247 \AA^{2}$, which is slightly higher than the value of $0.0218 \AA^{2}$ from the ELMAM refinement. The correlation coefficient between both $U_{\text {eq }}$ sets is only $95 \%$. With the IAM spherical atom model, the displacement parameters are incorrect as they incorporate some significant deformation electron density, due to improper deconvolution between these two features (Jelsch et al., 1998). The transferred multipolar refinement changes the values of the $U^{i j}$ thermal parameters and improves their accuracy.

When no rigid bond restraints are applied, the r.m.s. of the Hirshfeld (1976) test is $0.0042 \AA^{2}$ for the spherical atom and $0.0040 \AA^{2}$ for the multipolar atom model. As the Hirshfeld test was not satisfied, rigid bond restraints were applied in the refinement. The Hishfeld test may not systematically improve a lot in a multipolar atom refinement compared to a spherical atom model. This is partly because the bonding electron density shared between two atoms is generally located in the middle of the bond and the two $U^{i j}$ values are similarly perturbed along the bond direction when a spherical atom model is used. Also, the $U^{i j}$ values may be mainly affected by the errors in the diffraction data which explains the necessity here to use rigid bond restraints even in the multipolar refinement. The improvement of residual electron-density maps, of $R$ factors and of thermal $U^{i j}$ parameters is limited in

the case of this structure due to the predominance of errors in the diffraction data versus errors in electron-density modelling.

\section{Experimental}

To a solution of racemic secondary amine (I) (Bartsch \& Schwarz, 1983) $(0.32 \mathrm{~g}, 2 \mathrm{mmol})$ in absolute pyridine $(25 \mathrm{ml})$ at $277 \mathrm{~K}$ under an argon atmosphere were added benzoyl chloride dropwise ( $75 \mu 1,2$ equivalents) and 4-(dimethylamino)pyridine $(2 \mathrm{mg})$. The mixture was stirred for $14 \mathrm{~h}$ at room temperature and the solvent and reagent excess evaporated under reduced pressure. The residue was dissolved in $\mathrm{CH}_{2} \mathrm{Cl}_{2}(50 \mathrm{ml})$, washed with water $(3 \times 10 \mathrm{ml})$, isolated, dried over $\mathrm{MgSO}_{4}$, and finally concentrated under reduced pressure. The resulting gum solidified on standing in the dark and was crystallized from hot $96 \%$ EtOH to give colourless monocrystals [yield $78 \%$, 0.412 g; m.p. 434-435 K (Tottoli instrument)]. IR ( $\mathrm{NaCl}$ neat, $v$, $\left.\mathrm{cm}^{-1}\right)$ : 3056, 2948, 2361, 2350, 2240, 1657, 1495, 1370, 1266; ${ }^{1} \mathrm{H}$ NMR $\left(250 \mathrm{MHz}, \mathrm{CDCl}_{3}\right): \delta 3.81(d d, 1 \mathrm{H}, J=2.9$ and $13.9 \mathrm{~Hz}, \mathrm{H} 13), 4.74[d d$, $1 \mathrm{H}, J=3.6$ and $13.9 \mathrm{~Hz}, \mathrm{H} 15 A(B)], 5.3[t, 1 \mathrm{H}, J=3.3$ and $13.9 \mathrm{~Hz}$, $\mathrm{H} 15 B(A)], 6.7-6.8(m, 2 \mathrm{H}, \mathrm{Ar}), 6.95-7.1(m, 2 \mathrm{H}, \mathrm{Ar}), 7.35-7.65(m$, 5H, Bz); ES-MS ${ }^{+}$: $265.2(100)[M+\mathrm{H}]^{+}, 238.2(17)[M-\mathrm{CN}]^{+}$. Elemental analysis calculated for $\mathrm{C}_{16} \mathrm{H}_{12} \mathrm{~N}_{2} \mathrm{O}_{2}: \mathrm{C} 72.72, \mathrm{H} 4.58, \mathrm{~N}$ $10.60 \%$; found: C 73.02, H 4.48, N 10.66\%.

\section{Crystal data}

$\mathrm{C}_{16} \mathrm{H}_{12} \mathrm{~N}_{2} \mathrm{O}_{2}$

$M_{r}=264.28$

Monoclinic, $P 2_{1} / c$

$a=11.8920(4) \AA$

$b=7.3590(2) \AA$

$c=15.886(1) \AA$

$\beta=107.200(4)^{\circ}$

\section{Data collection}

Oxford Diffraction Xcalibur2 diffractometer

Absorption correction: multi-scan (CrysAlis RED; Oxford Diffraction, 2008)

$$
\begin{aligned}
& V=1328.06(11) \AA^{3} \\
& Z=4 \\
& \text { Mo } K \alpha \text { radiation } \\
& \mu=0.09 \mathrm{~mm}^{-1} \\
& T=100 \mathrm{~K} \\
& 0.35 \times 0.22 \times 0.17 \mathrm{~mm}
\end{aligned}
$$

Refinement

$R\left[F^{2}>2 \sigma\left(F^{2}\right)\right]=0.061$

$w R(F)=0.023$

$S=1.01$

4047 reflections

181 parameters

$$
\begin{aligned}
& T_{\min }=0.950, T_{\max }=1.000 \\
& (\text { expected range }=0.935-0.985) \\
& 53523 \text { measured reflections } \\
& 4047 \text { independent reflections } \\
& 2724 \text { reflections with } I>2 \sigma(I) \\
& R_{\text {int }}=0.032
\end{aligned}
$$

Least-squares refinement, based on $|F|$ using all reflections, was carried out with the program MOPRO (Guillot et al., 2001; Jelsch et al., 2005) using the ELMAM electron-density database (Zarychta $e t$ al., 2007). No reflection had a negative intensity. The weighted $R$ factor $w R$, conventional $R$ factor $R$ and goodness-of-fit $S$ are based on $F$. The threshold expression of $F^{2}>2 \sigma\left(F^{2}\right)$ is used only for calculating $R(F)$ and is not relevant to the choice of reflections for refinement. The reflection weights were set equal to $7.29 / \sigma^{2}\left(F_{\mathrm{o}}\right)$. The $U_{\text {iso }}(\mathrm{H})$ values were constrained to be $1.2 U_{\text {eq }}$ of the parent atom.

Data collection: CrysAlis CCD (Oxford Diffraction, 2008); cell refinement: CrysAlis RED (Oxford Diffraction, 2008); data reduction: CrysAlis RED; program(s) used to solve structure: SHELXS97 (Sheldrick, 2008); program(s) used to refine structure: MOPRO (Guillot et al., 2001; Jelsch et al., 2005); molecular graphics: 
Table 1

Selected geometric parameters $\left(\AA{ }^{\circ}\right)$.

\begin{tabular}{lrlr}
\hline $\mathrm{O} 1-\mathrm{C} 14$ & $1.227(1)$ & $\mathrm{N} 2-\mathrm{C} 14$ & $1.369(2)$ \\
$\mathrm{O} 2-\mathrm{C} 12$ & $1.370(2)$ & $\mathrm{N} 2-\mathrm{C} 15$ & $1.470(2)$ \\
$\mathrm{O} 2-\mathrm{C} 13$ & $1.434(2)$ & $\mathrm{C} 13-\mathrm{C} 16$ & $1.483(2)$ \\
$\mathrm{N} 2-\mathrm{C} 7$ & $1.424(2)$ & $\mathrm{N} 1-\mathrm{C} 16$ & $1.155(2)$ \\
& & & \\
$\mathrm{C} 7-\mathrm{N} 2-\mathrm{C} 14$ & $126.5(2)$ & $\mathrm{N} 2-\mathrm{C} 14-\mathrm{C} 1$ & $119.6(1)$ \\
$\mathrm{C} 7-\mathrm{N} 2-\mathrm{C} 15$ & $113.8(1)$ & $\mathrm{C} 13-\mathrm{C} 16-\mathrm{N} 1$ & $176.6(2)$ \\
$\mathrm{C} 14-\mathrm{N} 2-\mathrm{C} 15$ & $119.4(1)$ & $\mathrm{C} 13-\mathrm{C} 15-\mathrm{N} 2$ & $107.5(1)$ \\
$\mathrm{O} 1-\mathrm{C} 14-\mathrm{N} 2$ & $120.2(2)$ & $\mathrm{C} 15-\mathrm{C} 13-\mathrm{O} 2$ & $111.7(1)$ \\
$\mathrm{O} 1-\mathrm{C} 14-\mathrm{C} 1$ & $119.9(1)$ & $\mathrm{C} 16-\mathrm{C} 13-\mathrm{O} 2$ & $107.4(1)$ \\
& & & \\
$\mathrm{C} 1-\mathrm{C} 14-\mathrm{N} 2-\mathrm{C} 7$ & $20.9(1)$ & $\mathrm{C} 7-\mathrm{C} 12-\mathrm{O} 2-\mathrm{C} 13$ & $9.7(1)$ \\
$\mathrm{C} 1-\mathrm{C} 14-\mathrm{N} 2-\mathrm{C} 15$ & $-152.4(1)$ & $\mathrm{C} 12-\mathrm{O} 2-\mathrm{C} 13-\mathrm{C} 16$ & $84.3(1)$ \\
$\mathrm{C} 2-\mathrm{C} 1-\mathrm{C} 14-\mathrm{N} 2$ & $39.2(1)$ & $\mathrm{C} 12-\mathrm{O} 2-\mathrm{C} 13-\mathrm{C} 15$ & $-37.9(1)$ \\
$\mathrm{C} 7-\mathrm{N} 2-\mathrm{C} 14-\mathrm{O} 1$ & $-165.0(1)$ & $\mathrm{C} 12-\mathrm{C} 7-\mathrm{N} 2-\mathrm{C} 15$ & $26.6(1)$ \\
$\mathrm{C} 7-\mathrm{N} 2-\mathrm{C} 15-\mathrm{C} 13$ & $-52.8(1)$ & $\mathrm{C} 13-\mathrm{C} 15-\mathrm{N} 2-\mathrm{C} 14$ & $121.4(1)$ \\
$\mathrm{C} 8-\mathrm{C} 7-\mathrm{N} 2-\mathrm{C} 14$ & $36.6(1)$ & & \\
\hline
\end{tabular}

Table 2

Hydrogen-bond geometry $\left(\AA \stackrel{\circ}{\circ}^{\circ}\right)$.

$\mathrm{Cg}$ is the centroid of the $\mathrm{C} 7-\mathrm{C} 12$ ring.

\begin{tabular}{lllll}
\hline$D-\mathrm{H} \cdots A$ & $D-\mathrm{H}$ & $\mathrm{H} \cdots A$ & $D \cdots A$ & $D-\mathrm{H} \cdots A$ \\
\hline $\mathrm{C} 11-\mathrm{H} 11 \cdots \mathrm{O} 1^{\mathrm{i}}$ & 1.08 & 2.31 & $3.387(2)$ & 172 \\
$\mathrm{C} 13-\mathrm{H} 13 \cdots \mathrm{O} 1^{\mathrm{ii}}$ & 1.10 & 2.37 & $2.902(2)$ & 108 \\
$\mathrm{C} 13-\mathrm{H} 13 \cdots \mathrm{O} 2^{\text {iii }}$ & 1.10 & 2.43 & $3.068(2)$ & 115 \\
$\mathrm{C} 15-\mathrm{H} 15 B \cdots C g^{\text {iv }}$ & 1.09 & 2.57 & $3.633(2)$ & 165
\end{tabular}

Symmetry codes: (i) $x,-y+\frac{1}{2}, z+\frac{1}{2}$; (ii) $-x+1, y+\frac{1}{2},-z+\frac{1}{2}$; (iii) $-x+1,-y+1$, $-z+1$; (iv) $-x+1,-y,-z+1$.
SHELXTL (Sheldrick, 2008); software used to prepare material for publication: $M O P R O$.

Supplementary data for this paper are available from the IUCr electronic archives (Reference: GG3197). Services for accessing these data are described at the back of the journal.

\section{References}

Allen, F. H. (1986). Acta Cryst. B42, 515-522.

Bartsch, H. \& Schwarz, O. (1982). Arch. Pharm. (Weinheim), 315, 545-551.

Bartsch, H. \& Schwarz, O. (1983). J. Heterocycl. Chem. 20, 45-48.

Black, D. S. C., Craig, D. C., Heine, H. W., Kumar, N. \& Williams, E. A. (1987). Tetrahedron Lett. 28, 6691-6694.

Feng, G., Wu, J. \& Dai, W.-M. (2007). Tetrahedron Lett. 48, 401-404.

Garbauskas, M. F., Williams, E. A. \& Heine, H. W. (1985). Acta Cryst. C41, $1217-1222$.

Guillot, B., Viry, L., Guillot, R., Lecomte, C. \& Jelsch, C. (2001). J. Appl. Cryst. 34, 214-223.

Heine, H. W., Schairer, W. C., Suriano, J. A. \& Williams, E. A. (1988). Tetrahedron, 44, 3181-3186.

Hirshfeld, F. L. (1976). Acta Cryst. A32, 239-244.

Jelsch, C., Guillot, B., Lagoutte, A. \& Lecomte, C. (2005). J. Appl. Cryst. 38, $38-54$.

Jelsch, C., Pichon-Pesme, V., Lecomte, C. \& Aubry, A. (1998). Acta Cryst. D54, 1306-1318.

Myers, A. I. \& Sircar, J. C. (1970). In Chemistry of the Cyano Group, edited by Z. Rappaport, ch. 8. Belfast: John Wiley.

Oxford Diffraction (2008). CrysAlis CCD and CrysAlis RED. Versions 1.171.32.29. Oxford Diffraction Ltd, Abingdon, Oxfordshire, England.

Pichon-Pesme, V., Jelsch, C., Guillot, B. \& Lecomte, C. (2004). Acta Cryst. A60, 204-208.

Sheldrick, G. M. (2008). Acta Cryst. A64, 112-122.

Yu, M. \& Pagenkopf, B. L. (2003). J. Am. Chem. Soc. 125, 8122-8123.

Zarychta, B., Pichon-Pesme, V., Guillot, B., Lecomte, C. \& Jelsch, C. (2007). Acta Cryst. A63, 108-125. 